DOI: 10.2478/ausae-2021-0005

\title{
Understanding the influence of maize (Zea mays) and cowpea (Vigna unguiculata L. Walp) growth period on some thermal and hydrological properties of two soils with textural class variation
}

\author{
O. O. AKINGBOLA, ${ }^{1 *}$ C. O. AKINBILE, ${ }^{2}$ S. O. OJENIYI ${ }^{1}$ \\ ${ }^{1}$ Department of Crop, Soil and Pest Management, \\ Federal University of Technology, Akure, Nigeria \\ ${ }^{2}$ Department of Agricultural and Environmental Engineering, \\ Federal University of Technology, Akure, Nigeria \\ *Corresponding author: ooakingbola@futa.edu.ng
}

Manuscript received 25 June 2021; revised 30 July 2021; accepted 10 August 2021

\begin{abstract}
Adequate knowledge of soil processes is key to ensuring sustainability. Towards a better understanding of some thermal and hydrological processes that take place in the soil as a result of the growth period of maize and cowpea, a concurrent research was carried out in two different locations with soil textural variation (sandy clay loam and clay loam) at the Federal University of Technology, Akure. The treatment consisted of bare soil plot, cowpea plot, and maize plot arranged in a randomized complete block design in three replicates. The same weed management practice was carried out on all treatment plots throughout the duration of the study. Data were collected at 4 weeks after planting (WAP), 8 WAP, and 12 WAP, during which the dry bulk density, mass wetness, volumetric infiltration rate, saturated hydraulic conductivity, sorptivity, soil temperature, total energy emitted, wavelength of maximal radiation intensity, and energy flux were determined. The results showed that growing maize and cowpea had no significant influence $(\mathrm{P}>$ 0.05 ) on the soil properties measured in the SCL soil. However, significant difference was noticed in the CL soil at 8 WAP; the crops grown prevented the formation of excess soil seal and crust when compared to the bare soil plot. This study shows that soil textural property greatly influences hydrological and thermal processes in the soil during the maize and cowpea growth period.
\end{abstract}

Keywords: soil processes, maize growth, cowpea growth, soil texture 


\section{Introduction}

Soil sustainability can be said to be achieved if the production and nutritional quality of crops can be maintained over time without endangering the ecosystem and biodiversity [1]. The conservation of soil quality is fundamental to this sustainability. Healthy and productive soils are major to accomplishing about six of the sustainable development goals (SDG) adopted by the United Nations General Assembly [2, 3]. Our food systems are sustained by the soil while it filters water, sequestrates carbon, and supports numerous organisms. However, these soils are progressively under a lot of pressure from climate change, poor land management, and population growth [4]. In 2015, the 68 $8^{\text {th }}$ United Nations General Assembly began an evolution to raise awareness about the life-supporting functions of the soil [5]. This evolution triggered the need for improved understanding and sustainable management of this overlooked and abused natural resource called soil.

Land clearing of forested areas for crop production has been said to initiate processes that cause a rapid loss of carbon [6] and nitrogen from the soil; among others, this results in decline in soil quality termed as soil degradation [7, 8]. Total degradation of soil condition is critical because it is not easily naturally reversible [9]. This is because soil formation and regeneration processes are predominantly slow [10]. However, soil degradation is a gradual multifaceted process in which several features of soil deterioration can be recognized. Most of these degradative processes and their negative consequences can be controlled, prevented, abolished, or at least moderated if these processes are well understood. This prompted the need for this research to understand if maize and cowpea, which are commonly grown in the study area, have direct additional influence on some soil processes such as soil hydrological and thermal processes, which are majorly influenced by climate change while being crucial to soil sustainability. These soil processes are essential dynamic characteristics for assessing the influence of climate and agronomic management practices on the behaviour of soil. Soil temperature is an important attribute that influences soil biological, chemical, and physical quality [11]. It greatly influences the mineralization of various organic substances [12] and soil water availability [13]. Soil water, in turn, influences the interaction of the hydrological processes in the earth system [14]. One study claimed that agriculture threatens more plant and animal species worldwide than urban development and climate change combined [15]. This threat to biodiversity is a reminder of the urgency to understand the impacts of food production on the environment. 


\section{Materials and methods}

\section{Description of the study area}

The study, sited at two locations at the Federal University of Technology, Akure, Ondo State, Nigeria, was conducted from 21 April to 14 July in the year 2018. Location 1 was at the Teaching and Research Farm (Longitude: 5.145833; Latitude: 7.298889), while location 2 was at the Obakekere Junior Staff Quarters' Farm (Longitude: 5.123889; Latitude: 7.308889). Prior to the study, Location 1 had been left fallow for a period of 3 years after having been used for various research studies involving the addition of chemical and/or organic fertilizers, while Location 2 was used for cassava multiplication project but left fallow for about four years before the experiment. The major weeds identified on the plots were Tithonia diversifolia, Sida acuta, Imperata cylindrica, and Euphorbia heterophylla.

Akure is in the humid rainforest zone of south-western Nigeria [16]. The study area experiences distinct dry and wet seasons. The mean annual rainfall ranges from $1,405 \mathrm{~mm}$ to $2,400 \mathrm{~mm}$ [17]. The total monthly sunshine time is about 190 hours, while annual relative humidity is $80 \%$ [18]. The mean monthly rainfall, air temperature, and relative humidity data during the experiment are stated in tables 1 and 2. Rainfall data was sourced from the ERA5 of the Copernicus Climate Change Services, as described by [19], while air temperature and relative humidity data were sourced from the Modern-Era Retrospective Analysis for Research and Applications, version 2 (MERRA-2), using the Goddard Earth Observing System Model, Version 5 (GEOS-5) with its Atmospheric Data Assimilation System (ADAS), version 5.12.4.

Table 1. Mean monthly air temperature, rainfall, and humidity data during the experiment at the Teaching and Research Farm

(Longitude: 5.145833; Latitude: 7.298889)

\begin{tabular}{cccc}
\hline Months & $\begin{array}{c}\text { Air temperature } \\
\left({ }^{\circ} \mathbf{C}\right)\end{array}$ & Rainfall $(\mathbf{m m})$ & $\begin{array}{c}\text { Relative humidity } \\
\text { at 2 metres (\%) }\end{array}$ \\
\hline April & 24.90 & 111.6 & 86.76 \\
\hline May & 25.29 & 144.8 & 89.10 \\
\hline June & 24.40 & 208.7 & 90.95 \\
\hline July & 24.09 & 208.0 & 90.52 \\
\hline
\end{tabular}

Note: Elevation from MERRA-2 was at $292.62 \mathrm{~m}$ for air temperature and relative humidity. 
Table 2. Mean monthly air temperature, rainfall, and humidity data during the experiment at the Obakekere Junior Staff Quarters' Farm

(Longitude: 5.123889; Latitude: 7.308889)

\begin{tabular}{cccc}
\hline Months & $\begin{array}{c}\text { Air temperature } \\
\left({ }^{\mathbf{0}} \mathbf{C}\right)\end{array}$ & Rainfall (mm) & $\begin{array}{c}\text { Relative humidity } \\
\text { at 2 metres (\%) }\end{array}$ \\
\hline April & 25.77 & 106.5 & 86.76 \\
\hline May & 25.29 & 147.6 & 89.10 \\
\hline June & 24.37 & 200.0 & 90.95 \\
\hline July & 24.09 & 206.4 & 90.52 \\
\hline
\end{tabular}

Note: Elevation from MERRA-2 was at $292.62 \mathrm{~m}$ for air temperature and relative humidity.

\section{Experimental design and land preparation}

A land area measuring $60 \mathrm{~m} \times 60 \mathrm{~m}$ was ploughed and harrowed. A portion of the land was then divided into nine (9) experimental units of a total area of $225 \mathrm{~m}^{2}$ (15 m x $15 \mathrm{~m}$ ). Each unit had a dimension of $4 \mathrm{~m} \times 4 \mathrm{~m}$ and $1 \mathrm{~m}$ buffer zone between plots and also between blocks. The maize plot resulted in 36 plant stands per treatment plot at $75 \mathrm{~cm} \times 25 \mathrm{~cm}$ standard spacing, while the cowpea plot had 49 plants per treatment plot at $45 \mathrm{~cm} \mathrm{x} 45 \mathrm{~cm}$ standard spacing. The control plot was left bare.

\section{Planting material}

Late maturing cultivar Maize (TZB-SR) obtained from the International Institute of Tropical Agriculture (IITA) Ibadan, Oyo State, and Cowpea variety 07K-1311 obtained from the Seed Bank of the Plant Breeding Unit, Crop Soil and Pest Management Department, Federal University of Technology Akure, were used for the experiment.

\section{Experimental procedure}

The experiment consisted of three treatments, as indicated in Table 3. The soil was analysed for its inherent thermal, hydrological, and other essential physical properties prior to the experiment (before and after ploughing and harrowing), as stated in Table 4. All plots were put through the same agronomic management procedure. All weeds were uprooted manually and shaken to remove soil particles attached to the roots, after which the weeds were placed back on each plot as a means to recycle nutrients taken up by the weeds. This was done at 2 WAP, 4 WAP (after data collection), 6 WAP, 8 WAP (after data collection), and 10 WAP. 
Table 3. Treatment number, notation, and meaning

\begin{tabular}{ccc}
\hline Treatment number & Treatment notation & Meaning \\
\hline Treatment 1 & BSP & Bare Soil Plot (Control) \\
\hline Treatment 2 & CPP & Cowpea Plot \\
\hline Treatment 3 & MZP & Maize Plot \\
\hline
\end{tabular}

\section{Determination of soil hydrological properties}

\section{Mass wetness}

Mass wetness was determined at 4, 8 , and 12 WAP in the laboratory using the soil samples collected by applying the core method. The soil sample's weight before and after drying was measured. The water weight is the difference between the weights of the wet and oven-dry samples.

$M w=M t-M s$

Mass Wetness $(W m)=\left(\frac{M w}{M s}\right) * 100$,

where $\mathrm{Mw}$ is the mass of water in the soil sample expressed in grams, Mt is the mass of soil sample before drying, in grams, and Ms is the mass of soil sample after drying, in grams.

\section{Infiltration}

Infiltration is the entry of water into the soil through the soil-atmosphere interface. It was determined using a $10 \mathrm{~cm}$ diameter single-ring infiltrometer, as described by [20]. Cumulative infiltration rate is the total distance moved by water that entered into the soil in a specific period of time [20]. This was derived in $\mathrm{cm} / \mathrm{h}$ basis. Volumetric infiltration rate is the total volume of water that entered into the soil per time unit. This was derived as described by [21] in $\mathrm{cm}^{3} / \mathrm{h}$ basis using the formula below:

Volumetric infiltration rate $=\pi r^{2} *$ Cummulative Infiltration Rate

Sorptivity

Sorptivity, being the measure of the ability of the soil to absorb water, was derived at 4, 8, and 12 WAP for all plots, from cumulative infiltration as a function of the square root of time for a specific period of time, as described by [21, 20]: $S\left(\mathrm{~cm} / s^{-0.5}\right)=\frac{I}{\sqrt[2]{t}}$, 
where $\mathrm{S}$ is sorptivity, I is the cumulative infiltration, and $\mathrm{t}$ is the time in seconds.

\section{Saturated hydraulic conductivity}

Saturated hydraulic conductivity (Ksat) describes water movement through saturated media. Hydraulic conductivity depends on the intrinsic permeability of the material, the degree of saturation, and the density and viscosity of the fluid. It was estimated using the function presented by [22], which is:

$$
\begin{aligned}
& \text { Ksat }=1.15741 * 10^{-7} \exp (\mathrm{x}) \\
& \begin{aligned}
x=7.755+0.0352(\% S)+(0.93)-\left(0.967 * B D^{2}\right)-\left(0.000484 * \% C^{2}\right)-\left(0.000322 * \% S^{2}\right) \\
+\left(\frac{0.001}{\% S}\right)-\left(\frac{0.0748}{\% O M}\right)-(0.643 \ln \% S)-(0.01398 * B D * \% C) \\
-(0.1673 * B D * \% O M)+(0.02986 * \% C)-(0.03305 * \% S),
\end{aligned}
\end{aligned}
$$

where $\% \mathrm{C}$ is the percentage clay content of the soil, $\% \mathrm{~S}$ is the percentage silt content of the soil, and \%OM is the percentage organic matter content of the soil.

\section{Determination of soil thermal properties}

\section{Soil temperature}

Soil temperature was measured using soil thermometer placed $0-10 \mathrm{~cm}$ into the soil at about 15:00 hrs. The reading was reported in degree Celsius ${ }^{\circ} \mathrm{C}$.

\section{Total energy emitted}

The total energy emitted (Jt) was determined as described by [23] according to the Stephan-Boltzmann law. The law is represented by the formula below:

$J_{t}=\varepsilon \sigma T^{4}$,

where $\sigma$ is a constant which equals $5.670374419 e^{-8} \mathrm{watt} / \mathrm{m}^{2} / \mathrm{K}^{4}, \varepsilon$ is the emissivity coefficient -0.93 (the emissivity value of quartz) was used because quartz is usually the dominant mineral in soils -, and $\mathrm{T}$ is the soil temperature in Kelvin.

\section{Energy flux}

The energy flux $(E)$ emitted in a particular wavelength range (maximal wavelength) as determined using the Planck's law, which is represented by the equation below, was determined at 4,8 , and 12 WAP: 
$E_{\lambda}=C_{1} /\left[\lambda^{5}\left(\exp \left(C_{2} / \lambda T\right)-1\right)\right]$,

where $\mathrm{T}$ is the absolute temperature of the soil in Kelvin, $\lambda$ is the wavelength at temperature $\mathrm{T}, \mathrm{C}_{1}$ is a constant which equals $3.74177153 e^{-16} \mathrm{~W} \cdot \mathrm{m}^{2}$, and $\mathrm{C}_{2}$ is a constant which equals $1.4387770 e^{-2} \mathrm{~m} . \mathrm{K}$.

\section{Determination of other physical properties}

The particle size analysis of the soil was done using the standard hydrometer method described by [24], while the particle fraction was calculated using the formulae and the textural class triangle described by [25]. This resulted in the determination of the textural class of the soil. The bulk density was determined by core method [26].

\section{Data analysis}

The data were compiled into a Microsoft Excel (2016) spreadsheet and then subjected to analysis of variance (ANOVA) using statistical package for social sciences (SPSS v. 26), while the means were compared using Tukey's (HSD) test at $5 \%$ level of probability. The standard deviation values used for the error bars and all graphical representations were computed using Microsoft Excel (2016).

\section{Results}

Table 4. Status of the soils with textural class variation before the experiment

\begin{tabular}{lcccc}
\hline \multirow{2}{*}{ Soil properties } & \multicolumn{2}{c}{$\begin{array}{c}\text { Before ploughing and } \\
\text { harrowing }\end{array}$} & \multicolumn{2}{c}{$\begin{array}{c}\text { After ploughing and } \\
\text { harrowing }\end{array}$} \\
\cline { 2 - 5 } & $\begin{array}{c}\text { Sandy } \\
\text { clay loam }\end{array}$ & Clay loam & $\begin{array}{c}\text { Sandy } \\
\text { clay loam }\end{array}$ & Clay loam \\
\hline Clay (\%) & 20.7 & 37.9 & 22.9 & 38.2 \\
\hline Sand (\%) & 66.1 & 26.9 & 63.5 & 26.4 \\
\hline Silt (\%) & 13.2 & 35.2 & 13.6 & 35.4 \\
\hline Bulk density (g/cm $\left.{ }^{3}\right)$ & 1.48 & 1.59 & 1.29 & 1.38 \\
\hline Mass wetness $(\%)$ & 5.52 & 7.56 & 6.34 & 8.21 \\
\hline $\begin{array}{l}\text { Volumetric infiltration } \\
\left.\text { rate (cm }{ }^{3} / \mathrm{h}\right)\end{array}$ & 1,398 & 782 & 1,496 & 956 \\
\hline Sorptivity $\left(\mathrm{cm} / \mathrm{s}^{-0.5} \mathrm{E}-01\right)$ & 2.89 & 1.96 & 3.01 & 2.02 \\
\hline Soil temperature $\left({ }^{\circ} \mathrm{C}\right)$ & 33.24 & 32.25 & 35.54 & 33.46 \\
\hline Total energy emitted & 463.81 & 457.84 & 477.90 & 465.15 \\
\hline Energy flux $(\mathrm{E}-17)$ & 99.04 & 97.45 & 102.81 & 99.39 \\
\hline
\end{tabular}

Note: Mean values are presented in this table. 
Table 5. Soil hydrological properties in sandy clay loam and clay loam soils as affected by the treatments at 4,8 , and 12 WAP

\begin{tabular}{|c|c|c|c|c|c|c|}
\hline \multirow[b]{2}{*}{$\begin{array}{l}\text { Treat- } \\
\text { ment }\end{array}$} & \multicolumn{3}{|c|}{ Sandy clay loam soil } & \multicolumn{3}{|c|}{ Clay loam } \\
\hline & $\begin{array}{c}\text { Mass } \\
\text { wetness } \\
(\%)\end{array}$ & $\begin{array}{c}\text { Sorptivity } \\
\left(\mathrm{cm} / \mathrm{s}^{-0.5} \mathrm{E}-01\right)\end{array}$ & $\begin{array}{c}\text { Volumetric } \\
\text { infiltration } \\
\text { rate } \\
\left(\mathrm{cm}^{3} / \mathrm{h}\right)\end{array}$ & $\begin{array}{c}\text { Mass } \\
\text { wetness } \\
(\%)\end{array}$ & $\begin{array}{c}\text { Sorptivity } \\
\left(\mathrm{cm} / \mathrm{s}^{-0.5} \mathrm{E}-01\right)\end{array}$ & $\begin{array}{c}\text { Volumetric } \\
\text { infiltration } \\
\text { rate } \\
\left(\mathrm{cm}^{3} / \mathrm{h}\right)\end{array}$ \\
\hline \multicolumn{7}{|c|}{4 WAP } \\
\hline BSP & $6.77 \mathrm{a}$ & $3.20 \mathrm{a}$ & $1,507.07 \mathrm{a}$ & $11.14 \mathrm{a}$ & $2.01 \mathrm{a}$ & $946.93 a$ \\
\hline MZP & $7.26 a$ & $3.18 \mathrm{a}$ & $1,497.19 a$ & $11.26 \mathrm{a}$ & $1.87 \mathrm{a}$ & $879.64 a$ \\
\hline CPP & $7.75 a$ & $3.32 \mathrm{a}$ & $1,566.36 a$ & $11.44 \mathrm{a}$ & $1.88 \mathrm{a}$ & 886.68a \\
\hline \multicolumn{7}{|c|}{8 WAP } \\
\hline BSP & $6.79 \mathrm{a}$ & $3.16 \mathrm{a}$ & 1,491.36a & $10.94 b$ & $2.07 \mathrm{a}$ & 978.13a \\
\hline MZP & $7.27 \mathrm{a}$ & $3.14 \mathrm{a}$ & $1,481.48 \mathrm{a}$ & $11.58 \mathrm{ab}$ & $2.00 \mathrm{ab}$ & $944.24 \mathrm{ab}$ \\
\hline CPP & $7.75 \mathrm{a}$ & $3.29 \mathrm{a}$ & $1,550.65 \mathrm{a}$ & $11.93 \mathrm{a}$ & $1.97 \mathrm{~b}$ & $927.22 b$ \\
\hline \multicolumn{7}{|c|}{12 WAP } \\
\hline BSP & $6.93 a$ & $3.13 \mathrm{a}$ & $1,475.65 a$ & $12.27 \mathrm{a}$ & $2.03 a$ & $956.26 \mathrm{a}$ \\
\hline MZP & $7.38 \mathrm{a}$ & $3.09 \mathrm{a}$ & $1,457.92 \mathrm{a}$ & $12.43 \mathrm{a}$ & $2.05 \mathrm{a}$ & $964.85 \mathrm{a}$ \\
\hline СРP & $7.88 \mathrm{a}$ & $3.24 \mathrm{a}$ & $1,527.08 \mathrm{a}$ & $12.59 \mathrm{a}$ & $2.01 \mathrm{a}$ & $947.92 \mathrm{a}$ \\
\hline
\end{tabular}

Note: Means followed by the same letters in a column are not significantly $(\mathrm{P}>0.05)$ different according to Tukey's Honestly Significant Difference (HSD) test. WAP - Weeks after planting.

Table 6. Soil thermal properties in sandy clay loam and clay loam soils as affected by the treatments at 4,8 , and 12 WAP

\begin{tabular}{|c|c|c|c|c|c|c|}
\hline \multirow[b]{2}{*}{$\begin{array}{l}\text { Treat- } \\
\text { ment }\end{array}$} & \multicolumn{3}{|c|}{ Sandy clay loam soil } & \multicolumn{3}{|c|}{ Clay loam } \\
\hline & $\begin{array}{c}\text { Soil } \\
\text { tempe- } \\
\text { rature } \\
\left({ }^{\circ} \mathrm{C}\right)\end{array}$ & $\begin{array}{c}\text { Total } \\
\text { energy } \\
\text { emitted } \\
\text { (watt } / \mathbf{m}^{2} \text { ) }\end{array}$ & $\begin{array}{c}\text { Energy } \\
\text { flux (E-17) }\end{array}$ & $\begin{array}{c}\text { Soil } \\
\text { tempe- } \\
\text { rature }\left({ }^{\circ} \mathrm{C}\right)\end{array}$ & $\begin{array}{c}\text { Total } \\
\text { energy } \\
\text { emitted } \\
\text { (watt/m²) }\end{array}$ & $\begin{array}{c}\text { Energy } \\
\text { flux (E-17) }\end{array}$ \\
\hline \multicolumn{7}{|c|}{4 WAP } \\
\hline BSP & $35.28 \mathrm{a}$ & 476.30a & $102.38 \mathrm{a}$ & $32.57 \mathrm{a}$ & $459.70 \mathrm{a}$ & 97.97a \\
\hline MZP & $35.20 \mathrm{a}$ & $475.79 a$ & $102.25 \mathrm{a}$ & $32.83 a$ & $461.47 a$ & $98.40 \mathrm{a}$ \\
\hline CPP & $34.71 \mathrm{a}$ & 472.78a & $101.44 \mathrm{a}$ & $32.27 \mathrm{a}$ & $458.00 \mathrm{a}$ & $97.50 \mathrm{a}$ \\
\hline \multicolumn{7}{|c|}{8 WAP } \\
\hline BSP & $35.04 \mathrm{a}$ & $474.82 \mathrm{a}$ & $101.99 a$ & $33.47 \mathrm{a}$ & $465.11 \mathrm{a}$ & 99.37a \\
\hline MZP & $34.96 a$ & $474.32 \mathrm{a}$ & $101.85 \mathrm{a}$ & $32.30 \mathrm{ab}$ & $458.11 \mathrm{ab}$ & $97.53 \mathrm{ab}$ \\
\hline CPP & $34.48 \mathrm{a}$ & 471.38a & 101.06a & $31.70 \mathrm{~b}$ & $454.63 \mathrm{~b}$ & $96.60 \mathrm{~b}$ \\
\hline
\end{tabular}




\begin{tabular}{|c|c|c|c|c|c|c|}
\hline \multirow[b]{2}{*}{$\begin{array}{l}\text { Treat- } \\
\text { ment }\end{array}$} & \multicolumn{3}{|c|}{ Sandy clay loam soil } & \multicolumn{3}{|c|}{ Clay loam } \\
\hline & $\begin{array}{c}\text { Soil } \\
\text { tempe- } \\
\text { rature } \\
\left({ }^{\circ} \mathrm{C}\right)\end{array}$ & $\begin{array}{c}\text { Total } \\
\text { energy } \\
\text { emitted } \\
\left(\text { watt } / \mathbf{m}^{2} \text { ) }\right.\end{array}$ & $\begin{array}{c}\text { Energy } \\
\text { flux (E-17) }\end{array}$ & $\begin{array}{c}\text { Soil } \\
\text { tempe- } \\
\text { rature }\left({ }^{\circ} \mathrm{C}\right)\end{array}$ & $\begin{array}{c}\text { Total } \\
\text { energy } \\
\text { emitted } \\
\left(\text { watt } / \mathbf{m}^{2} \text { ) }\right.\end{array}$ & $\begin{array}{c}\text { Energy } \\
\text { flux (E-17) }\end{array}$ \\
\hline \multicolumn{7}{|c|}{12 WAP } \\
\hline BSP & $34.99 \mathrm{a}$ & $474.49 \mathrm{a}$ & 101.90a & $35.40 \mathrm{a}$ & $477.17 \mathrm{a}$ & $102.67 \mathrm{a}$ \\
\hline MZP & $34.91 \mathrm{a}$ & 473.99a & $101.76 a$ & $33.17 \mathrm{a}$ & $463.41 \mathrm{a}$ & $99.00 \mathrm{a}$ \\
\hline CPP & $34.43 a$ & $471.07 a$ & $100.98 a$ & $32.90 \mathrm{a}$ & $461.77 \mathrm{a}$ & $98.53 a$ \\
\hline
\end{tabular}

Note: Means followed by the same letters in a column are not significantly $(\mathrm{P}<0.05)$ different according to Tukey's Honestly Significant Difference (HSD) test. WAP - Weeks after planting.

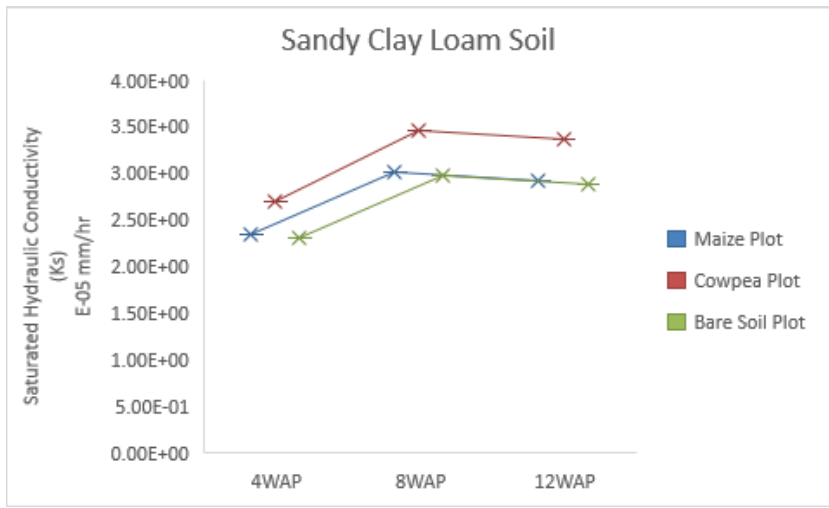

Figure 1. Saturated Hydraulic Conductivity (Ks E-05) in a sandy clay loam soil as affected by the treatments at 4,8 , and 12 WAP

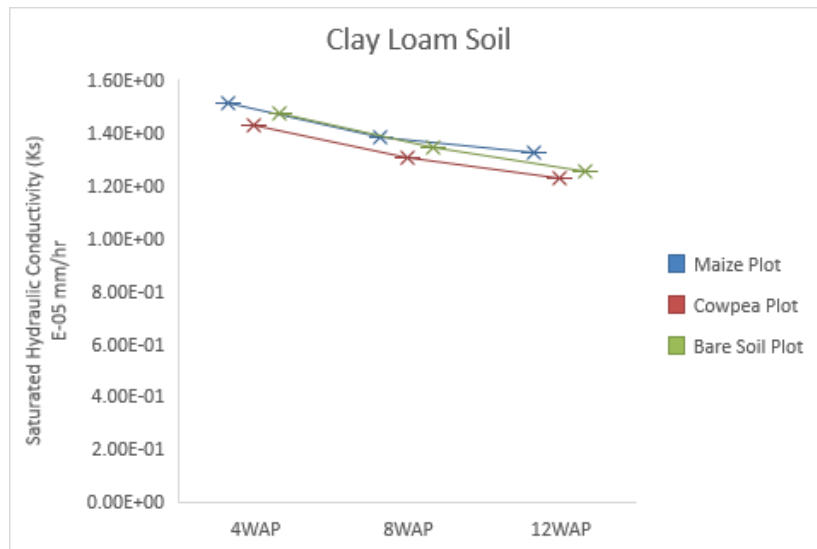

Figure 2. Saturated Hydraulic Conductivity (Ks E-05) in a clay loam soil as affected by the treatments at 4,8 , and 12 WAP 


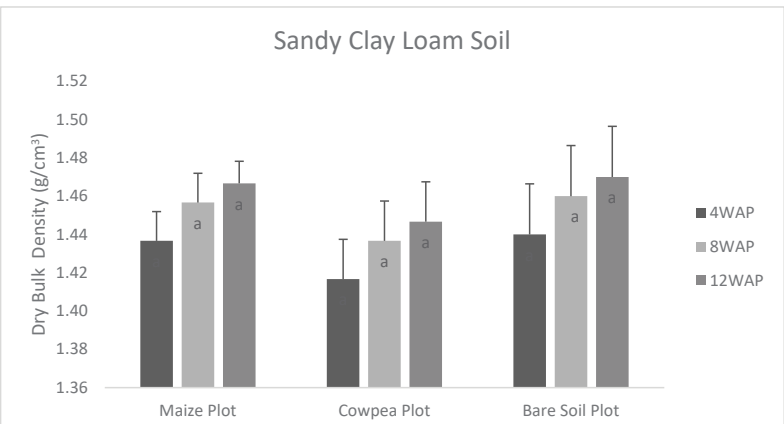

Note: Error bars correspond to the standard deviation and compared to the control (0B) (P > 0.05).

Figure 3. Dry Bulk Density $\left(\mathrm{g} / \mathrm{cm}^{3}\right)$ in a sandy clay loam soil as affected by the treatments at 4,8 , and 12 WAP

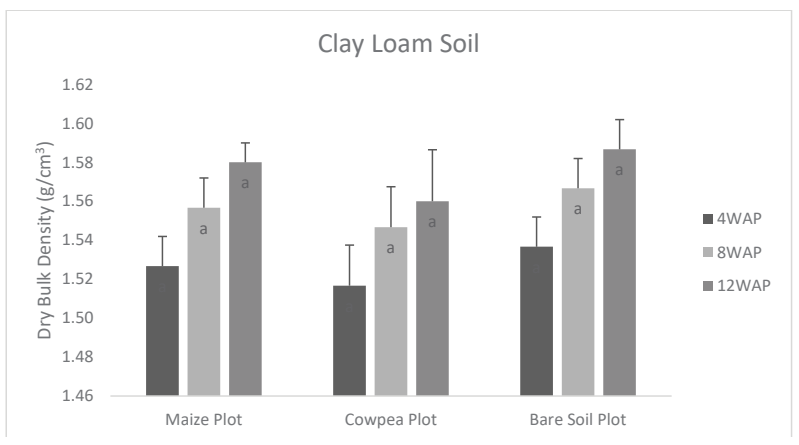

Note: Error bars correspond to the standard deviation and compared to the control (0B) $(\mathrm{P}>0.05)$.

Figure 4. Dry Bulk Density $\left(\mathrm{g} / \mathrm{cm}^{3}\right)$ in a clay loam soil as affected by the treatments at 4,8 , and 12 WAP

\section{Discussion}

Status of the soils with textural class variation before the experiment

The status of the study prior to the experiment is shown in Table 4. The textures of the soils were sandy clay loam (SCL) and clay loam (CL), although a variation in individual values of the sand, clay, and silt content were noticed before and after ploughing and harrowing. The bulk density of the SCL and CL were 1.48g/ $\mathrm{cm}^{3}$ and $1.59 \mathrm{~g} / \mathrm{cm}^{3}$, resp., before ploughing and harrowing and $1.38 \mathrm{~g} / \mathrm{cm}^{3}$ and 
$1.29 \mathrm{~g} / \mathrm{cm}^{3}$, resp., afterwards. The values recorded for the volumetric infiltration rate, soil temperature, and sorptivity were lower in CL compared with the SCL.

\section{Soil hydrological properties in sandy clay loam and clay loam soils as affected by the treatments}

Maize and cowpea growth influence on soil hydrological properties of the SCL and CL are presented in Table 5. At 4, 8, and 12 WAP, there was no significant difference $(\mathrm{P}>0.05)$ among the treatment mean values for mass wetness in SCL. This means that the presence of cowpea or maize on the plot did not significantly influence the amount of water stored in the SCL soil throughout the experiment. However, there was a trend revealing that the cowpea plot stored more water in the soil $(7.75 \%$ at 4 WAP and 8 WAP, $7.88 \%$ at 12 WAP), while the bare soil plot had the least amount (6.77\% at 4 WAP, $6.79 \%$ at 8 WAP, $6.93 \%$ at $12 \mathrm{WAP}$ ) despite not being significantly different $(\mathrm{P}>0.05)$. This trend was probably due to the shading effect of the broad leaves of the cowpea, thereby reducing water loss. [27] concluded that a decrease in vegetative cover would cause an increase in soil temperature, which will accelerate moisture loss.

In the CL soil, the only significant difference $(\mathrm{P}<0.05)$ recorded was at 8 WAP. This was when the highest difference was observed between the control (BSP), which had the lowest mean value (10.94\%), and CPP, which had the highest $(11.93 \%)$. This was probably due to an on-site observation, which was noted while conducting the study. Soil seal and crust formation were noticeable on the BSP compared to MZP and CPP, thereby probably reducing the amount of water infiltrated and retained. This phenomenon is in line with the finding of [28] although the sealing and crusting were kept in check due to leaving uprooted weeds (organic matter) on the soil surface after the agronomic maintenance of all plots, as recommended by [29].

Comparing the mass wetness values of the soils of the experimental location, it was expected that the CL soil would have a higher water content than the SCL soil. It has been concluded that soils with higher sand percentage would allow easier drainage of water than storage, while soils with a higher clay content have a greater ability to adsorb water than soils with higher percentage of sand [30].

The volumetric infiltration rate (VIR) and sorptivity were the inverses of the mass wetness trend. High mean values for mass wetness resulted in a low volume of water infiltrated into the soil per hour. This is probably due to the inherent moisture content of soil being a highly crucial factor when considering its infiltration capacity [31, 32]. There was no significant difference $(\mathrm{P}>0.05)$ among the mean values recorded for the VIR and sorptivity as a result of the treatments on the SCL soil. 
With reference to Figure 1 and Figure 2, MZP and CPP had no significant impact on the saturated hydraulic conductivity (Ks) mean values recorded in both SCL and CL soils compared to the BSP. However, there is a difference in trend with regard to SCL and CL. There was a downward trend in Figure 2, which shows that Ks was higher at 4 WAP and reduced subsequently at 8 WAP and 12 WAP in CL soils. The initial increase was probably due to the agitated state of the soil after ploughing and harrowing, and as the soil settled with time, there was probably a reduction in the ease with which water moved in the CL soil. Also, comparing the Ks mean values for the SCL and CL, it was observed the SCL had higher values compared to CL. This observation could have been accounted for by many factors such as the level of macroporosity and compaction. Several researchers have concluded that the hydraulic conductivity of clay-sand mixtures decreases with the increase in clay percentage [33, 34, 35]. Also, the SCL had a lower compaction level compared to CL. This was reflected through the mean values of dry bulk density.

\section{Soil thermal properties in sandy clay loam and clay loam soils as affected by the treatments}

Table 6 shows the mean values describing the thermal properties of the soil as a result of the treatment. There was no significant difference $(\mathrm{P}>0.05)$ among the soil temperature (ST) mean values in the SCL soil. However, the trend shows that $\mathrm{CPP}$ had the least mean value for the soil temperature at $4\left(34.71{ }^{\circ} \mathrm{C}\right), 8\left(34.48{ }^{\circ} \mathrm{C}\right)$, and 12 WAP $\left(34.43{ }^{\circ} \mathrm{C}\right)$ followed by MZP $\left(35.20^{\circ} \mathrm{C}\right.$ at 4 WAP, $34.96{ }^{\circ} \mathrm{C}$ at 8 WAP, $34.91{ }^{\circ} \mathrm{C}$ at $12 \mathrm{WAP}$ ), while the highest mean values recorded were for the BSP $\left(35.28{ }^{\circ} \mathrm{C}\right.$ at $4 \mathrm{WAP}, 35.04{ }^{\circ} \mathrm{C}$ at $8 \mathrm{WAP}, 34.99{ }^{\circ} \mathrm{C}$ at $\left.12 \mathrm{WAP}\right)$. This result is in line with the findings of [36], who concluded that soil temperature was higher for the plot with sole maize than for the plot with sole cowpea. The trend recorded in the SCL was replicated in the CL. However, there was a significant difference $(\mathrm{P}<0.05)$ among treatments in the CL at 8 WAP only. This significant difference at 8 WAP under thermal properties was the same as with the hydrological properties. It has been concluded in a previous study that soil hydrological properties and thermal properties are closely linked [27]. Water has also been found to have a cooling effect in soils.

The values recorded for total energy emitted (TEE) during the study were directly proportional to the soil temperature mean values. It is assumed that the same amount of solar energy was directed at all experimental plots since there was no form of shading on any section of the total plot area. It can be concluded that energy not emitted by the soil was absorbed by the plants through a process called photosynthesis, thereby causing the BSP to have a higher TEE compared to MZP and CPP. This means that energy received per unit area by the MZP and CPP was put to good use towards ensuring food security. 
Energy flux (EF) is the rate of transfer of energy in the soil. EF is also presented in Table 6. There was no significant difference $(\mathrm{P}>0.05)$ among treatments in the SCL; however, at 8 WAP, there was significant difference $(\mathrm{P}<0.05)$ among treatments in the CL. According to the mean values recorded, it was noted that the rate of energy transfer in SCL was higher than the values recorded for CL. This was probably because moisture stored in the CL was higher than in the SCL, thereby causing a cooling effect, which reduced the soil temperature.

\section{Other soil physical properties in sandy clay loam and clay loam soils as affected by the treatments}

According to figures 3 and 4, the mean values of the bulk density (BD) for the SCL and CL soils increased across the weeks for all treatments despite not being significantly different $(\mathrm{P}>0.05)$.

The CPP had the lowest mean value for BD $\left(1.42 \mathrm{~g} / \mathrm{cm}^{3}\right.$ at $4 \mathrm{WAP}, 1.44 \mathrm{~g} / \mathrm{cm}^{3}$ at $8 \mathrm{WAP}$, and $1.45 \mathrm{~g} / \mathrm{cm}^{3}$ at $12 \mathrm{WAP}$ ), while MZP and BSP had the same mean values in the SCL soil $\left(1.44 \mathrm{~g} / \mathrm{cm}^{3}\right.$ at $4 \mathrm{WAP}, 1.46 \mathrm{~g} / \mathrm{cm}^{3}$ at $8 \mathrm{WAP}$, and $1.47 \mathrm{~g} / \mathrm{cm}^{3}$ at 12 WAP); however, there was no similarity in the standard deviation (SD) values of MZP and BSP as depicted by the error bars. The values recorded for BSP deviated more from the mean value compared to MZP.

The same trend as above was noticed for the treatments in the CL soil, where CPP had the least mean values for BD $\left(1.52 \mathrm{~g} / \mathrm{cm}^{3}\right.$ at $4 \mathrm{WAP}, 1.55 \mathrm{~g} / \mathrm{cm}^{3}$ at $8 \mathrm{WAP}$, and $1.56 \mathrm{~g} / \mathrm{cm}^{3}$ at $\left.12 \mathrm{WAP}\right)$ followed by the MZP $\left(1.53 \mathrm{~g} / \mathrm{cm}^{3}\right.$ at $4 \mathrm{WAP}, 1.56 \mathrm{~g} / \mathrm{cm}^{3}$ at $8 \mathrm{WAP}$, and $1.58 \mathrm{~g} / \mathrm{cm}^{3}$ at $12 \mathrm{WAP}$ ), while the BSP had the highest recorded mean value for all weeks $\left(1.54 \mathrm{~g} / \mathrm{cm}^{3}\right.$ at $4 \mathrm{WAP}, 1.57 \mathrm{~g} / \mathrm{cm}^{3}$ at $8 \mathrm{WAP}$, and $1.59 \mathrm{~g} / \mathrm{cm}^{3}$ at 12 WAP). However, the same mean values were not calculated for MZP and BSP in CL soil compared to SCL soil.

The increased bulk density of the soil throughout the week must have been due to the resettling of the soil to a resting state after the initial ploughing and harrowing that was done to prepare the land for cultivation. This must have also been aided by the wetting and drying cycle that the soil went through; this process has been concluded to stimulate aggregation in a laboratory experiment conducted by [37]. The BD mean values of the SCL were generally lower than the mean values of the CL soil; this is probably due to the textural component of the soils. In line with this, [38] discovered that sandy soil was less compacted by harvesting machines compared to clayey soils.

\section{Conclusions}

This study has shown that despite the physiological differences in maize and cowpea, there is no significant influence on the hydrological and thermal properties 
of the SCL soil measured in this research. However, the crops grown influenced soil seal and crust formation in the CL soil positively. More soil seal and crust were noticeable on the bare soil, thereby increasing run-off and reducing infiltration. Therefore, the soil textural property greatly influences hydrological and thermal processes in the soil during the maize and cowpea growth period. It can also be concluded that the soil thermal properties have direct effect on the hydrological properties of the soil.

\section{References}

[1] White, P. J., Crawford, J. W., Álvarez, M. D., Moreno, R. G. (2014), Soil management for sustainable agriculture 2013. Applied and Environmental Science 2014, art. nr. 536825. https://doi.org/10.1155/2014/536825.

[2] Keesstra, S. D., Bouma, J., Wallinga, J., Tittonell, P., Smith, P., Cerdà, A., Montanarella, L., Quinton, J. N., Pachepsky, Y., Van der Putten, W. H., Bardgett, R. D., Moolenaar, S., Mol, G., Jansen, B., Fresco, L. O. (2016), The significance of soils and soil science towards realization of the United Nations Sustainable Development Goals. SOIL 2, 111-128. https://doi.org/10.5194/ soil-2-111-2016.

[3] Nhemachena, C., Matchaya, G., Nhemachena, C. R., Karuaihe, S., Muchara, B., Nhlengethwa, S. (2018), Measuring baseline agriculture-related sustainable development goals index for Southern Africa. Sustainability 10(3), art. nr. 849. https://doi.org/10.3390/su10030849.

[4] Ajayi, A. S. (2015), Land degradation and the sustainability of agricultural production in Nigeria: A review. Journal of Soil Science and Environmental Management 6(9), 234-240. https://doi.org/10.5897/JSSEM15.0507.

[5] Rojas, R. V., Caon, L. (2016), The international year of soils revisited: Promoting sustainable soil management beyond 2015. Environmental Earth Sciences 75, art. nr. 1184. https://doi.org/10.1007/s12665-016-5891-z.

[6] Olorunfemi, I. E., Fasinmirin, J. T., Olufayo, A. A., Komolafe, A. A. (2020), Total carbon and nitrogen stocks under different land use/land cover types in the Southwestern region of Nigeria. Geoderma Regional 22, art. nr. e00320. Elsevier BV. https://doi.org/10.1016/j.geodrs.2020.e00320.

[7] Saha, R., Chaudhary, R. S., Somasundaram, J. (2012), Soil health management under hill agroecosystem of North East India. Applied and Environmental Soil Science 2012, art. nr. 696174. https://doi.org/10.1155/2012/696174.

[8] Ayoubi, S., Moazzeni Dehaghani, S. (2020), Identifying impacts of land use change on soil redistribution at different slope positions using magnetic susceptibility. Arabian Journal of Geoscience 13, art. nr. 426. https://doi. org/10.1007/s12517-020-05383-x. 
[9] Eswaran, H., Lal, R., Reich. P. F. (2001), Land degradation: An overview. In: Bridges, E. M., Hannam, I. D., Oldeman, L. R., Pening de Vries, F. W. T., Scherr, S. J., Sompatpanit, S. (eds.), Responses to land degradation. Proc. of the $2^{\text {nd }}$ International Conference on Land Degradation and Desertification, Khon Kaen, Thailand. Oxford Press, New Delhi, India.

[10] Hurni, H. (1988), Degradation and conservation of the resources in the Ethiopian highlands. African Mountains and Highlands May-Aug., 123-130. https://doi.org/10.2307 / 3673438.

[11] Buchan, G. D. (2001), Soil temperature regime. In: Smith, K. A., Mullins, E. D. (eds.), Soil and environmental analysis: Physical methods. Marcel Dekker, New York. 539-594.

[12] Davidson, E. A., Janssens, I. A. (2006), Temperature sensitivity of soil carbon decomposition and feedbacks to climate change. Nature. 440(7081), 165173. https://doi.org/10.1038/nature04514.

[13] Onwuka, B. M. (2016), Effects of soil temperature on some soil properties and plant growth. Scholarly Journal of Agricultural Science 6(3), 89-93.

[14] Pan, Y. X., Wang, X. P. (2009), Factors controlling the spatial variability of surface soil moisture within revegetated-stabilized desert ecosystems of the Tengger Desert, Northern China. Hydrological Processes 23(11), 1591-1601. https://doi.org/10.1002/hyp.7287.

[15] Kanianska, R. (2016), Agriculture and its impact on land-use, environment, and ecosystem services. landscape ecology - The influences of land use and anthropogenic impacts of landscape creation. IntechOpen. https://doi. org/10.5772/63719.

[16] Akinbile C. O., Erazua A. E., Babalola T. E., Ajibade F. O. (2016), Environmental implications of animal wastes pollution on agricultural soil and water quality. Soil and Water Research 11, 172-180.

[17] Akinbile, C. O., Eze, R. C., Yusuf, H., Ewulo, B. S., Olayanju, A. (2019), Effect of some selected soil properties, moisture content, yield and consumptive water use on two cassava (TMS 0581 and TME 419) varieties. Journal of Agricultural Engineering L, 919. https://doi.org/10.4081/jae.2019.919.

[18] Ajibefun, I. A. (2008), An evaluation of parametric and non-parametric methods of technical efficiency measurement: Application to small scale food crop production in Nigeria. Journal of Agriculture and Social Sciences 4(3), 95-100.

[19] Bidlot, J-R., Abdalla, S., Hersbach, H. (2017), ERA5 wave data. Proceedings from the $19^{\text {th }}$ EGU General Assembly. 23-28 April 2017, Vienna, Austria, pp. 8707.

[20] Adeyemo, A. J., Akingbola, O. O., Ojeniyi, S. O. (2019), Effects of poultry manure on soil infiltration, organic matter contents and maize performance on two contrasting degraded alfisols in southwestern Nigeria. International 
Journal of Recycling of Organic Waste in Agriculture 8, 73-80. https://doi. org/10.1007/s40093-019-0273-7.

[21] Akingbola, O. O., Adeyemo, A. J., Oladele, S. O., Ojeniyi, S. O. (2016), Physical status and infiltration dynamics of tropical Alfisol of South-Western Nigeria as affected by poultry manure. Applied Tropical Agriculture 21(3), 102-111. https://www.futa.edu.ng/journal/home/paperd/90/5/11 (accessed on: 12 December 2019).

[22] Wösten, J. H. M., Lilly, A., Nemes, A., Le Bas, C. (1999), Development and use of a database of hydraulic properties of European soils. Geoderma 90, 169-185.

[23] Hillel, D. (1980), Fundamentals of soil physics. New York: Academic Press.

[24] Gee, G. W., Bauder J. W. (1986), Particle-size analysis. In: Klute, A. (ed.), Methods of soil analysis. Part 1. Physical and mineralogical methods. $2^{\text {nd }}$ ed. SSSA Book Series 5. ASA and SSSA, Madison. 383-411. http://dx.doi. org/10.1108/09593840110411167.

[25] Okalebo, R. J., Gathua, K. W., Woomer, P. L. (2002), Laboratory methods of soil and plant analysis: A working manual. Nairobi, Kenya: Sacred Africa.

[26] Blake, G. R., Hartge, K. H. (1986), Bulk density. In: Klute, A. (ed.), Methods of soil analysis: Part I. Physical and mineralogical methods. ASA, Madison, WI. 363- 375.

[27] Yhang, W., Wang, Y., He, C., Tan, X., Han, Z. (2019), Soil water content and temperature dynamics under grass land degradation: A multi-depth continuous measurement from the agricultural pastoral ecotone in Northwest China. Sustainability 11, art. nr. 4188. https://doi.org/10.3390/su11154188.

[28] Nciizah, A. D., Wakindiki, I. I. C. (2015), Physical indicators of soil erosion, aggregate stability and erodibility. Archives of Agronomy and Soil Science 61(6), 827-842. https://doi.org/10.1080/03650340.2014.956660.

[29] Lv, C., Bi, R., Guo, X., Chen, D., Guo, Y., Xu, Z. (2020), Erosion characteristics of different reclaimed substrates on iron tailings slopes under simulated rainfall. Scientific Reports 10, art. nr. 4275. https://doi.org/10.1038/s41598020-61121-z.

[30] Howe, J. A., Barrientos-Velazquez, A. (2020), Teaching water movement in soil through experiential activities. Natural Sciences Education 49(1), e20012. https://doi.org/10.1002/nse2.20012.

[31] Merz, B., Plate, E. J. (1997), An analysis of the effect of spatial variability of soil and soil moisture on runoff. Water Resources Research 33, 2909-2922. https://doi.org/10.1029/97WR02204.

[32] Western, A. W., Zhou, S. L., Grayson, R. B., McMahon, T. A., Bloschl, G., Wilson, D. J. (2004), Spatial correlation of soil moisture in small catchments and its relationship to dominant spatial hydrological processes. Journal of Hydrology 286, 113-134. https://doi.org/10.1016/j.jhydrol.2003.09.014. 
[33] Chapuis, R. P. (1990), Sand-bentonite liners: Predicting permeability from laboratory tests. Canadian Geotechnical Journal 27, 47-57.

[34] Sivapullaiah, P., Sridharan, A., Stalin, V. (2000), Hydraulic conductivity of bentonite-sand mixtures. Canadian Geotechnical Journal 37, 406-413.

[35] Komine, H. (2008), Theoretical equations on hydraulic conductivities of bentonite-based buffer and backfill for underground disposal of radioactive wastes. Journal of Geotechnical and Geoenvironmental Engineering 134, 497-508.

[36] Ghanbari, A., Dahmardeh, M., Siahsar, B. A., Ramroudi, M. (2010), Effect of maize (Zea mays L.) - cowpea (Vigna unguiculata L.) intercropping on light distribution, soil temperature and soil moisture in arid environment. Journal of Food, Agriculture and Environment 1, 102-108. https://doi. org/10.1234/4.2010.1458.

[37] Akingbola, O. O., Dayo-Olagbende, G. O., Ojeniyi, S. O. (2020), Differentiated short-term influence of plant and animal based biochar on the microaggregation of two texturally soils. Sustainability in Food and Agriculture 1(2), 48-52. https://sfna.org.my/sfna-02-2020-48-52/ (accessed on: 24 July 2020).

[38] Ampoorter, E., De Schrijver, A., Van Nevel, L., Hermy, M., Verheyen, K. (2012), Impact of mechanized harvesting on compaction of sandy and clayey forest soils: Results of a meta-analysis. Annals of Forest Science 69, 533-542. https://doi.org/10.1007/s13595-012-0199-y. 